\title{
Histological Comparative Study between the Possible Effect of Stem Cells and $\alpha$-Lipoic Acid on Rat Testes Treated by Cyclophosphamide
}

\section{Original Article}

\author{
Eman Mostafa Sadek', Dalia Hussein Abdel Aziz', Azza Saleh Embaby ${ }^{2}$, and \\ Gaber Fekry Genedy ${ }^{2}$
}

Department of Histology, Faculty of Medicine, ${ }^{\text {IC Cairo University and }}{ }^{2}$ Beni-Suef University.

\begin{abstract}
Background and Objectives: Testicular dysfunction is the most common side effect of chemotherapeutics as cyclophosphamide (CP). Stem cells (SCs) transplantation has become a new therapeutic strategy in the treatment of male infertility. Lipoic acid (LA) is one of the effective antioxidants. This work aimed to evaluate the histological changes induced by CP on the rat testes and the possible ameliorating role of SCs and LA.

Methods and Results: 37 male albino rats were divided into: group A (Control), group B (experimental) that received intra peritoneal (IP) injection of $15 \mathrm{ml} / \mathrm{kg} \mathrm{CP}$ for $6 \mathrm{wks}$. Then, they were subdivided into 5 subgroups: B1 (model) continued receiving CP for 11 wks, B2 (SCs) injected IP with single dose of SCs (1x106 per animal), B3 (LA) injected IP with both CP and LA (10 mg/kg/every other day) for 11 wks, B4 (SCs + LA) treated with both SCs and LA and B5 (recovery) left without any treatment for 11 wks. Histological, immunohistochemical and morphometric studies were performed. B1 and $\mathrm{B} 5$, revealed the toxic effect of $\mathrm{CP}$; such as atrophy, degeneration, incomplete spermatogenic series in most seminiferous tubules. Spermatogenic and Leydig cells showed negative immunoreaction with $\mathrm{BCl} 2$. These changes were ameliorated in B2, B3andB4.These ameliorations were better in B4 than in B2andB3.

Conclusions: $\mathrm{CP}$ can induce testicular lesions in rats. Withdrawal of CP does not ameliorate these effects. The concomitant administration of SCs and LA with CP improved these lesions. Meanwhile combined treatment with SCs + LA resulted in better improvement more than using each one of them singly.
\end{abstract}

Received: 10 December 2018, Accepted: 27 February 2019

Key Words: CP, LA, SCs, testicular injury.

Corresponding Author: Azza Saleh Embaby, MD, Department of Histology, Faculty of Medicine, Beni-Suef University, Egypt, Tel.: +20 1119001589, E-mail: azza_embaby2010@yahoo.com

ISSN: 1110-0559, Vol. 42, No. 3

\section{INTRODUCTION}

Testicular tissues are commonly attacked by many antineoplastic cytotoxic agents and immunosuppressant medications. These materials significantly affect the patient's capacity of having his own biological offspring. In many cases, the capacity to accomplish a pregnancy might be temporarily diminished, compelling the patient to postpone parenthood and sometimes sterility might be permanent $t^{[1]}$.

The application of Cyclophosphamide (CP) in the treatment of some leukemia, lymphomas, and solid malignancies is so common. Human and animal models treated with $\mathrm{CP}$ showed reproductive toxicity as the main side effect of the drug. Gonadal toxicity, which can lead to sterility in humans, is caused by long-dated treatment with CP for cancers. Many records have specified that $\mathrm{CP}$ indisposes the oxidant-antioxidant balance of tissues and raises the production of intracellular reactive oxygen species (ROS). The oxidative stress that leads to cellular damage is mainly related to the imponderables between the production of ROS and the lowering of antioxidative mechanisms $^{[2]}$.
Mesenchymal stem cells (MSCs) transplantation has turned to be a new curative planning for the treatment of male sterility. The reports evidenced that MSCs could collaborate in spermatogenesis ${ }^{[3]}$. They have been detected in many tissues such as adipose tissue and extra embryonic tissues. They are able to be induced to differentiate into cells of mesenchymal lineage and form male germ cells, bone, cartilage or fat ${ }^{[4,5]}$.

MSCs have a great appeal for cell therapy and tissue engineering in treatment of testicular injury for numerous reasons. They are relatively easy to procure, multiply rapidly in culture and show only petty spontaneous differentiation during ex vivo expansion. They are multi potential and form supportive stroma for hematopoiesis. They seem to be largely immunologically inert, paving the way for allogenic and xenogenic transplantation. They are immunosuppressive and secrete numerous trophic agents which alter inflammation, remodeling and apoptosis ${ }^{[6,7]}$.

Lipoic acid (LA) is a powerful antioxidant that works against oxygen radicals in testicular tissue ${ }^{[8,9]}$. Many reports demonstrated that LA protects the testis against a wide spectrum of toxic agents where oxidative stress is a part of the underlying etiology ${ }^{[9,10]}$. 
The present study aimed at investigating the possible therapeutic effect of MSCs as a line of treatment for experimentally induced testicular injury by $\mathrm{CP}$ in comparison to the effect of LA in male albino rat.

\section{MATERIALS AND METHODS}

\section{Drugs}

- Cyclophosphamide: In the form of endoxan vials of $200 \mathrm{mg}$, each vial was dissolved in $10 \mathrm{mg}$ saline (Multipharma for Pharmaceuticals and Chemicals Company, Egypt).

- Alpha-Lipoic acid (Thiotacid): was obtained as pack of five ampoules each of them is $10 \mathrm{mg}$ solution (EVA pharma for pharmaceuticals and Medical Apliances, Egypt).

- Bone Marrow-derived Mesenchymal Stem Cells (BMD-MSCs): purchased from Biochemistry Department, Faculty of medicine, Cairo University.

\begin{abstract}
Animals
Thirty seven four months old adult male albino rats weighing 150-200 g were used and divided into 2 groups placed in separate cages. The animals were kept under good hygienic conditions, fed ad libitum and allowed for free water supply. The experiment was performed in the Animal House of Kasr Al Ainy, Faculty of Medicine,Cairo University. The rats were treated in accordance with guidelines approved by the Animal Use Committee of Cairo University. The rats were divided into the following groups:
\end{abstract}

* Group A (Control group): 10 rats, each of them was injected intraperitoneally (IP) by $10 \mathrm{mg} / \mathrm{kg}$ body weight saline for 17 weeks ${ }^{[11]}$.

* Group B (Experimental group): 27 rats were IP injected by CP $15 \mathrm{mg} / \mathrm{kg}$ body weight dissolved in saline every other day for 6 weeks. Two rats were sacrificed to confirm testicular injury ${ }^{[12]}$ then the rest of animals were subdivided into 5 subgroups (5 animals per group) as following:

- SubgroupB1 (CP treated): Rats were IP injected with $\mathrm{CP}$ at a dose of $15 \mathrm{mg} / \mathrm{kg} /$ body weight dissolved in saline every other day for 11 weeks ${ }^{[11]}$.

- Subgroup B2 (Stem cells subgroup): Rats received $\mathrm{CP}$ as in subgroup $\mathrm{B} 1$ and single dose of BMD-MSCs (1x106 per animal) injected into the tail vein ${ }^{[12]}$

- SubgroupB3 (LA subgroup): Rats received CP as in subgroup B1 and LA ampoules administered (IP) to the animals at a dose of $10 \mathrm{mg} / \mathrm{kg}$ / every other day dissolved in saline for 11 weeks $^{[13]}$.

- Subgroup B4 (Stem cells plus LA subgroup): Rats received $\mathrm{CP}$ as in subgroup $\mathrm{B} 1+\mathrm{BMD}-\mathrm{MSC}$ as in subgroup B2+ LA as in group B3 ${ }^{[12,13]}$
- Subgroup B5 (Recovery group): Rats were left without any drug treatment for 11 weeks ${ }^{[12]}$.

At the end of experiment, all rats were sacrificed by over dose of anesthesia $(100 \mathrm{mg} / \mathrm{kg}$ ketamine-xylazaine $\mathrm{IP}^{[14]}$ and testes were removed after an abdominal incision that was extended to the perineal region. The scrotal sacs were opened and the testes were removed.

\section{Preparation of BMD-MSCs from rats}

\section{a) Isolation}

Bone marrow was harvested by flushing the tibiae and femurs of 6 weeks old male albino rats with Dulbecco's modified Eagle's medium (DMEM) supplemented with $10 \%$ fetal bovine medium .Nucleated cells were isolated with a density gradient and resuspended in complete culture medium supplemented with $1 \%$ penicillinstreptomycin. Cells were incubated at $37^{\circ} \mathrm{C}$ in $5 \%$ humidified carbon dioxide for 12 to 14 days as primary culture or upon formation of large colonies. When large colonies developed (80-90\% confluence), cultures were washed twice with phosphate buffer saline (PBS) and cells were trypsinized with $0.25 \%$ trypsin for 5 minutes at $37 \circ$ C. After centrifugation (at $2400 \mathrm{rpm}$ for 20 minutes), cells were resuspended with serum supplemented medium and incubated in $50 \mathrm{~cm} 2$ culture flask Falcon. The resulting cultures were referred to as first passage cultures ${ }^{[15]}$.

\section{b) Morphological Identification}

MSCs in culture were characterized by their adhesiveness and fusiform shape ${ }^{[16]}$.

\section{c) Labeling of MSCs with PKH26 dye}

MSCs were harvested during the 4th passage and were labeled with PKH26 fluorescent linker dye. PKH26 is a red fluorochrome, has excitation of $551 \mathrm{~nm}$ and emission equals $567 \mathrm{~nm}$. It is physiologically stable and shows little to no toxic side effects on cell systems. Labelled cells retain both biological and proliferating activity. Labelled cells that have been washed can be visualized in culture up to 100 days after staining (for non-dividing cells). The dye itself is stable and will divide equally when the cells divide $^{[17]}$

\section{(1) Histological study}

a. Hematoxylinand Eosin staining ${ }^{[18]}$.

b. Masson's trichrome staining ${ }^{[19]}$.

c. Immunohistochemical studies with $\mathrm{BCl}_{2}$ onchoprotein $^{[20]}$.

\section{(2) Detection of homing of MSCs}

labeled with PKH26 fluorescent dye in testicular tissue with immunofluorescent microscope.

\section{(3) Morphometric study}

using Leica Qwin 500 (Leica LTD, Cambridge, UK) image analysis, assessment of the mean area $\%$ of collagen 
fibers. and mean area $\%$ of $\mathrm{BCl}_{2}$ in all groups were measured using an objective lens of magnification 10 for collagen fibers and 40 for $\mathrm{BCl}_{2}$. Ten fields were measured for each specimen. Using the colour detects blue collagen and brown immunostained areas were masked by a blue binary colour. The area \% was calculated in relation to a standard measuring frame of area 118476.6 micrometer square for collagen fibers and 7286.78 micrometer square for $\mathrm{BCl}_{2}$.

\section{(4) Statistical analysis}

Quantitative data were summarized as means and standard deviations and compared using one-way analysis of variance (ANOVA). Results were considered significant when probability $p<0.05$, highly significant when $p<0.01$ and very highly significant when $p<0.001^{[21]}$.

\section{RESULTS}

No deaths were observed in all rats.

\section{Hematoxylin and eosin (HandE) stained sections}

Section of testis of control rats (group I) demonstrated seminiferous tubules that were lined by spermatogenic cells and intact basement membrane. The interstitial cells of Leydig appeared scattered between the seminiferous tubules (Figure 1A). Myoid cells appeared as flat cells at the basement membrane of seminiferous tubules and the tails of late spermatids were observed. The interstitial cells of Leydig appeared rounded with acidophilic cytoplasm and pale nuclues with prominent nucluelus (Figure 1B).

In subgroup B1 (Model subgroup), most of the seminiferous tubules appeared markedly distorted (Figure 1C).Multiple cytoplasmic vacuolations were seen in the tubules. The interstitial tissue is showing Leydig cells with dark nuclei and congested capillaries (Figure 1D).

Insubgroup B2(Stemcellssubgroup), someseminiferous tubules appeared with regular outline while others were still distorted .The interstitial cells of Leydig were scattered in between the tubules. The seminiferous tubules appeared lined by more or less normal spermatogenic cells .The interstitial tissue contained normally arranged Leydig cells (Figure 1E).Some seminiferous tubules appeared with mostly preserved arrangement of the spermatogonic cells and few cytoplasmic vacuolations. The seminiferous tubulesappeared lined with more or less normal spermatogenic cells;spermatogonia, 1ry spermatocytes andspermatids. The interstitial tissue showed interstitial cells of Leydig with acidophilic cytoplasm (Figure 1F).

In subgroup B3 (LA subgroup), numerous seminiferous tubules appeared distorted (Figure 2A). Some seminiferous tubules appeared with intact basament membrane, cytoplasmic vacuolations and spermatogenic cells with dark nuclei.The interstitial cells of Leydig showed acidophilic cytoplasm and atypical dark nuclei (Figure 2B).
In subgroup B4 (Stem cells plus LA subgroup), most of seminiferous tubules were apparently normal.The interstitial tissue revealed nearly normal Leydig cells (Figure 2C). Most of seminiferous tubules appeared lined by nearly normal spermatogenic cells; spermatogonia, 1ry spermatocytes and intact basement membrane. The interstitial tissue appeared with nearly normal Leydig cells with acidophilic cytoplasm (Figure 2D).

Insubgroup B5 (Recovery subgroup), multiple seminiferous tubules appeared with depleted spermatogenic cells. The interstitial tissue showed congestion of peritubular blood capillaries (Figure 2E). The seminiferous tubules revealed disrupted basement membrane and distorted spermatogenic epithelium with marked cytoplasmic vacuolation. The interstitial tissue showed congested blood vessels and Leydig cells with dark atypical nuclei (Figure 2F).

\section{Masson's trichrome stained sections}

No apparent interstitial collagen fibers deposition in sections of testes of control rats (Figure 3A). While model subgroup showed massive amount of collagen fibers deposition in between the tubules (Figure 3B). Stem cells subgroup showed fine collagen fibers deposition inbetween seminiferous tubules(Figure 3C). LA subgroup displayed dense perivascular and peritubular collagen fibers deposition (Figure 3D). Stem cells plus LA subgroup revealed no apparent collagen fibres deposition (Figure 3E). While recovery subgroup showed seminiferous tubules with massive collagen fibers deposition in the peritubular space and around blood capillary (Figure 3F).

\section{Immunohistochemical studies with $\mathrm{BCl}_{2}$ onchoprotein}

Positive $\mathrm{BCl}_{2}$ immunoexpression was found in the cytoplasm of the spermatogenic and Leydig cells in sections of testes of control rats (Figure 4A). While model subgroup showed negative $\mathrm{BCl}_{2}$ immunoreaction in the cytoplasm of spermatogenic cells and Leydig cells (Figure 4B). Stem cells subgroup showed+ve $\mathrm{BCL}_{2}$ immunoreactions in the cytoplasm of their spermatogenic cells and Leydig cells (Figure 4C). LA subgroup showed negative $\mathrm{BCL}_{2}$ immunoreaction in the cytoplasm of the spermatogenic cells and positive $\mathrm{BCl}_{2}$ immunoreaction in the cytoplasm of Leydig cells (Figure 4D). Stem cells plus LA subgroup revealed moderate $+\mathrm{veBCL}_{2}$ immunoreaction in the cytoplasm of spermatogenic cells and Leydig cells (Figure 4E). While recovery subgroup showed negative $\mathrm{BCl}_{2}$ immunoreaction in the cytoplasm of spermatogenic cells as well as in the cytoplasm of Leydig cells (Figure 4F).

\section{Homing of transplanted MSCs}

Testicular section of subgroups B2 (Figure 5A) and B4 (Figure 5B) showed homing of transplanted MSCs (yellow arrows) in testicular tissue. 


\section{Morphometric results}

A significant increase in mean area \% of collagen fibres content was recorded in subgroups B1, B3 and B5 compared to control and subgroups B2 and B4
(Figure 6A and Table 1). The area $\%$ of $\mathrm{BCL}_{2}$ immunoexpression denoted a significant decrease in subgroups B1, B3 and B5 compared to control and subgroups B2 and B4 (Figure 6B and Table 2).
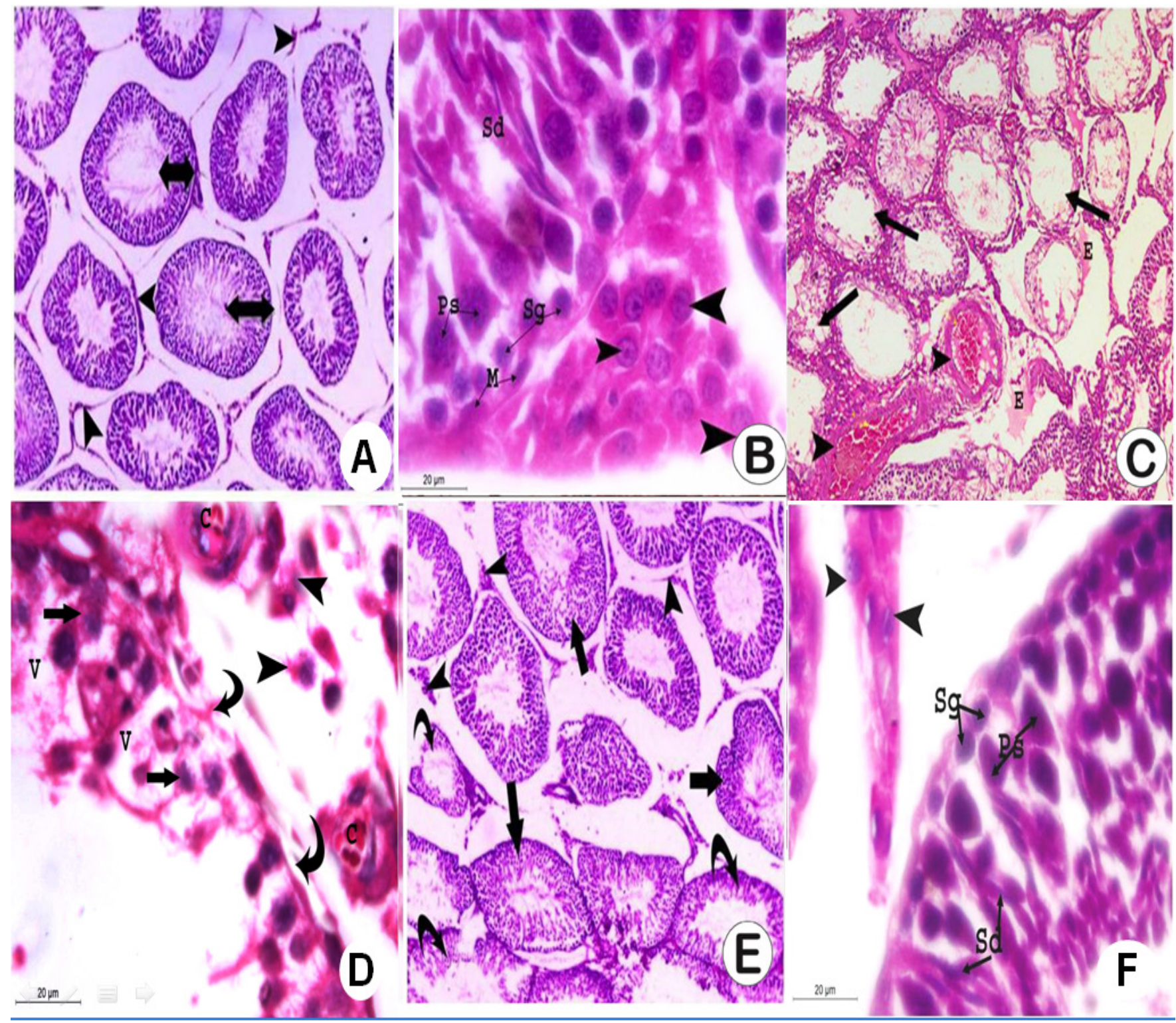

Fig. 1: (A) showing semineferous tubules lined by spermatogenic cells (double headed arrow). The interstitial cells of Leydig are scattered between the semineferous tubules (arrowheads).(group A,H\&E $\times 100$ ).(B) showing a part of seminiferous tubules lined by spermatogonia (Sg), primary spermatocytes (Ps) and Myoid cells(M). The tails of late spermatids ( $\mathrm{Sd}$ ) are observed. The interstitial cells of Leydig (arrowheads) appear scattered between the seminiferous tubules (group A, H\&E $\times 1000$ ). (C) showing marked distortion in most of the seminiferous tubules that appeared distorted and vacuolated (black arrows) with homogeneous material (E) and congested blood vessels (arrowheads) in between tubules (subgroup B1, H\&E x 100). (D) showing irregular distorted seminiferous tubules (black arrows).The basement membrane of the tubules appeared irregular and distorted (curved arrows). Multiple cytoplasmic vacuolations(V) were seen in the tubules. The interstitial tissue is showing Leydig cells with dark nuclei (arrowheads) and congested capillaries (C) (subgroup B1,H\&E X 1000).(E)showing some seminiferous tubules with regular outline (black arrows)while other are still distorted (curved arrows). The interstitial cells of Leydig are scattered in between the tubules (arrowheads) ( subgroup B2,H\& E x100). (F)showing the seminiferous tubules lined with more or less normal spermatogenic cells;spermatogonia (Sg), 1ry spermatocytes (Ps) \& spermatids ( $\mathrm{Sd}$ ). The interstitial tissue showed interstitial cells of Leydig (arrowheads) with acidophilic cytoplasm (subgroup B2, H\&Ex1000). 


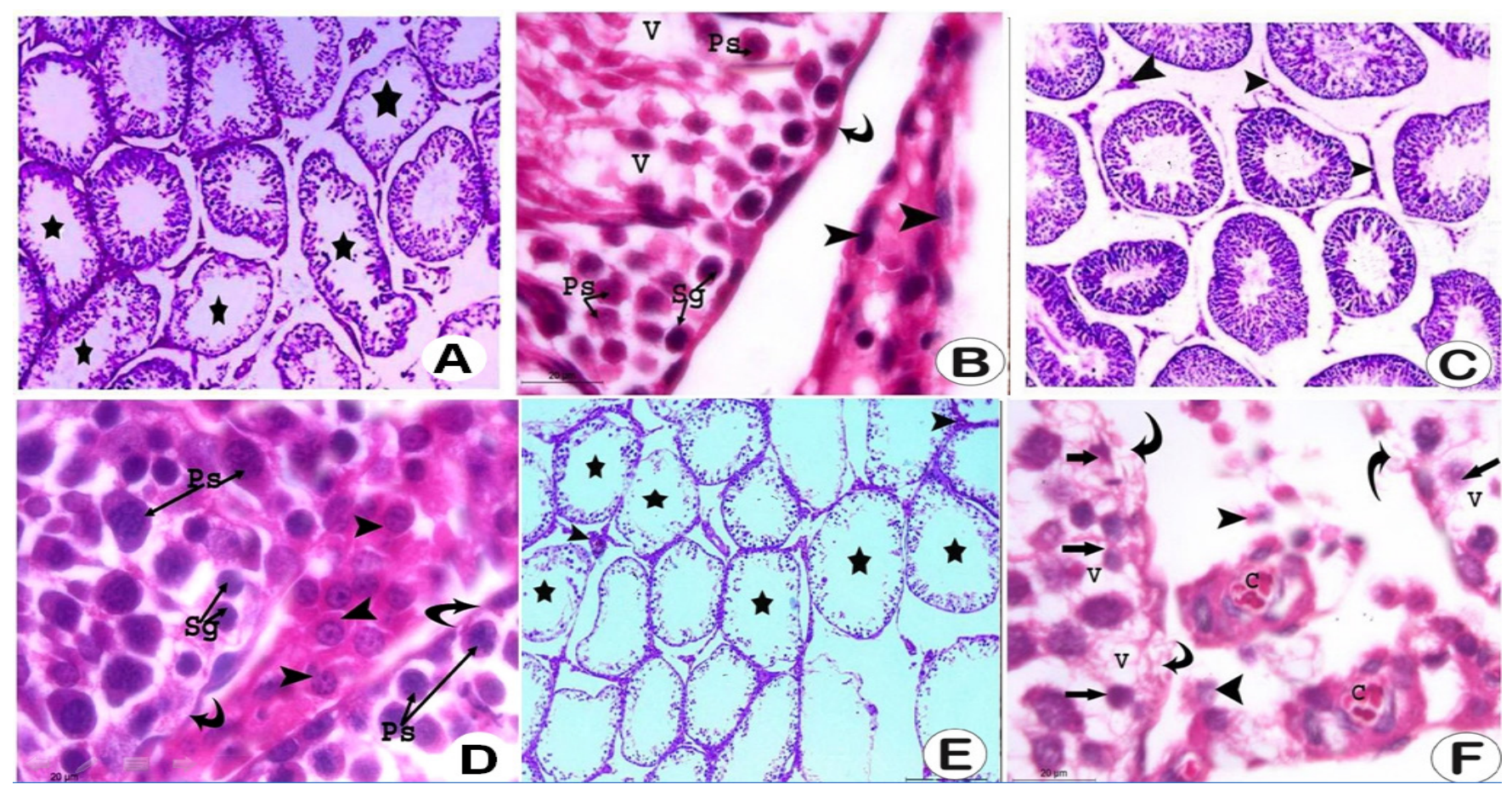

Fig. 2: (A) showing numerous seminiferous tubules appeared distorted (stars). (subgroup B3, H\&E X100).(B)showing a part of seminiferous tubule with intact basament membrane (curved arrow) cytoplasmic vacuolations (V) \& spermatogenic cells with dark nuclei; spermatogonia (Sg), distorted 1ry spermatocytes(Ps). The interstitial cells of Leydig (arrowheads) scattered in between the tubules with acidophilic cytoplasm and atypical dark nuclei ( subgroup B3, H\&EX1000).(C) showing apparently normal seminiferous tubules and interstitial cells of Leydig (arrowheads) in between. (subgroupB4,H\&E x100). (D)showing a seminiferous tubules lined by nearly normal spermatogenic cells; spermatogonia (Sg), 1ry spermatocytes (Ps) and intact basement membrane (curved arrows). The interstitial tissue appeared with nearly normal Leydig cells (arrowheads) with acidophilic cytoplasm (subgroup B4, H\& E x1000). (E) showing multiple tubules with depleted spermatogenic cells(stars). The interstitial tissue is showing congestion of peritubular blood capillaries (arrowheads) (subgroup B5,H\&EX100).(F)showing the seminiferous tubules with disrupted basement membrane (curved arrows) and distorted spermatogenic epithelium (black arrows) with marked cytoplasmic vacuolation (V).The interstitial tissue is showing congested blood vessels (C) and Leydig cells with dark atypical nuclei (arrowheads) (subgroup B5,H\&EX1000).

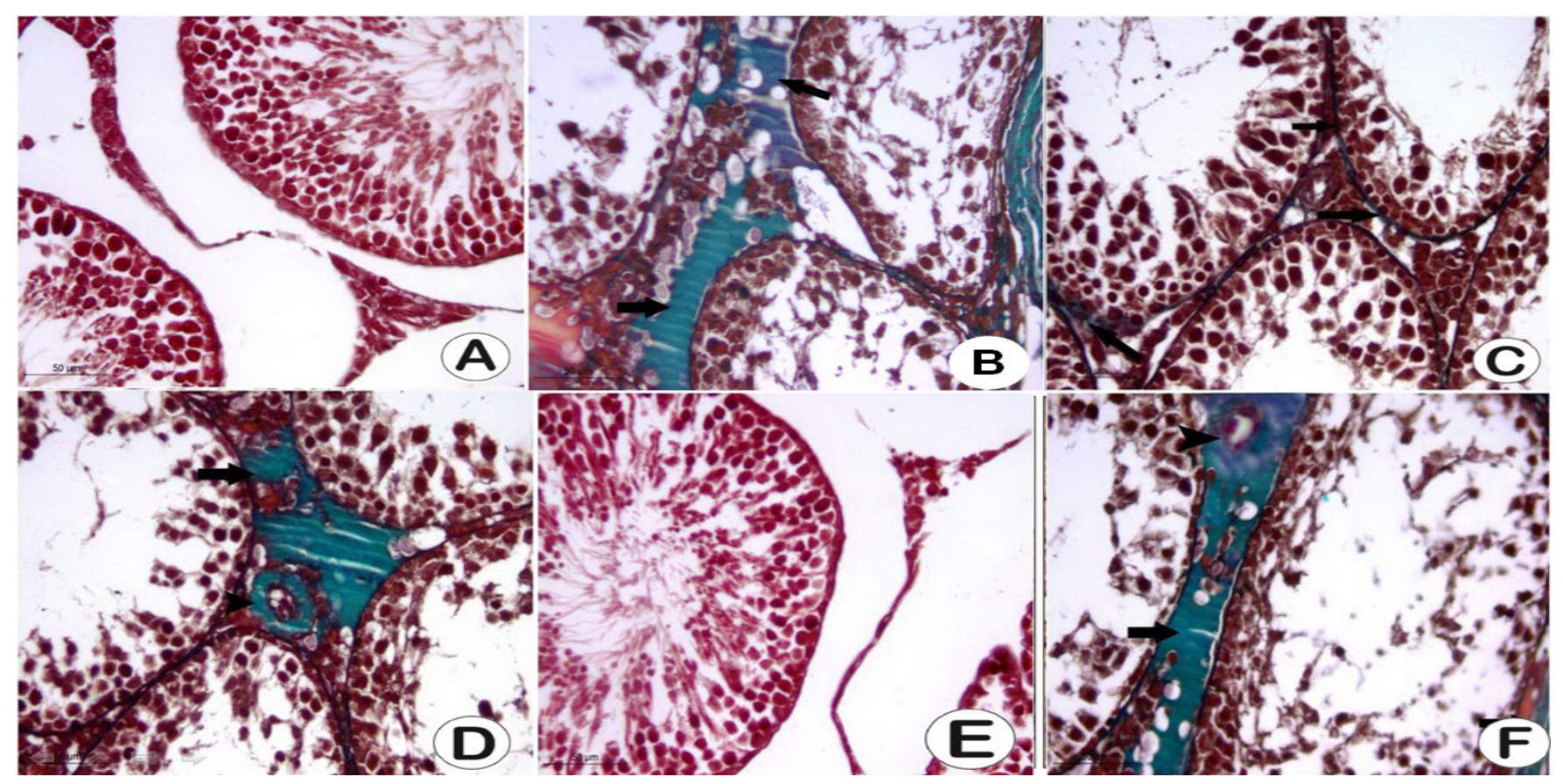

Fig. 3: (A) showing no apparent interstitial fibers (group A ,Masson's trichrome x400).(B)showing massive amount of collagen fibers deposition in between the tubules (black arrows) (subgroup B1,Masson's trichrome x 400).(C)showing fine collagen fibers deposition around seminiferous tubules (black arrow) (subgroup B2 ,Masson's trichrome x400).(D)displaying dense perivascular (arrowhead) and peritubular (black arrow) collagen fibers deposition (subgroup B3, Masson's Trichrome x 400). (E) showing no apparent collagen fibres deposition(subgroup B4 ,Masson's trichrome x400). (F)showing seminiferous tubules with massive collagen fibers deposition in the peritubular space (black arrows) and around blood capillary (arrowhead)(subgroup B5 ,Masson's trichromeX400). 


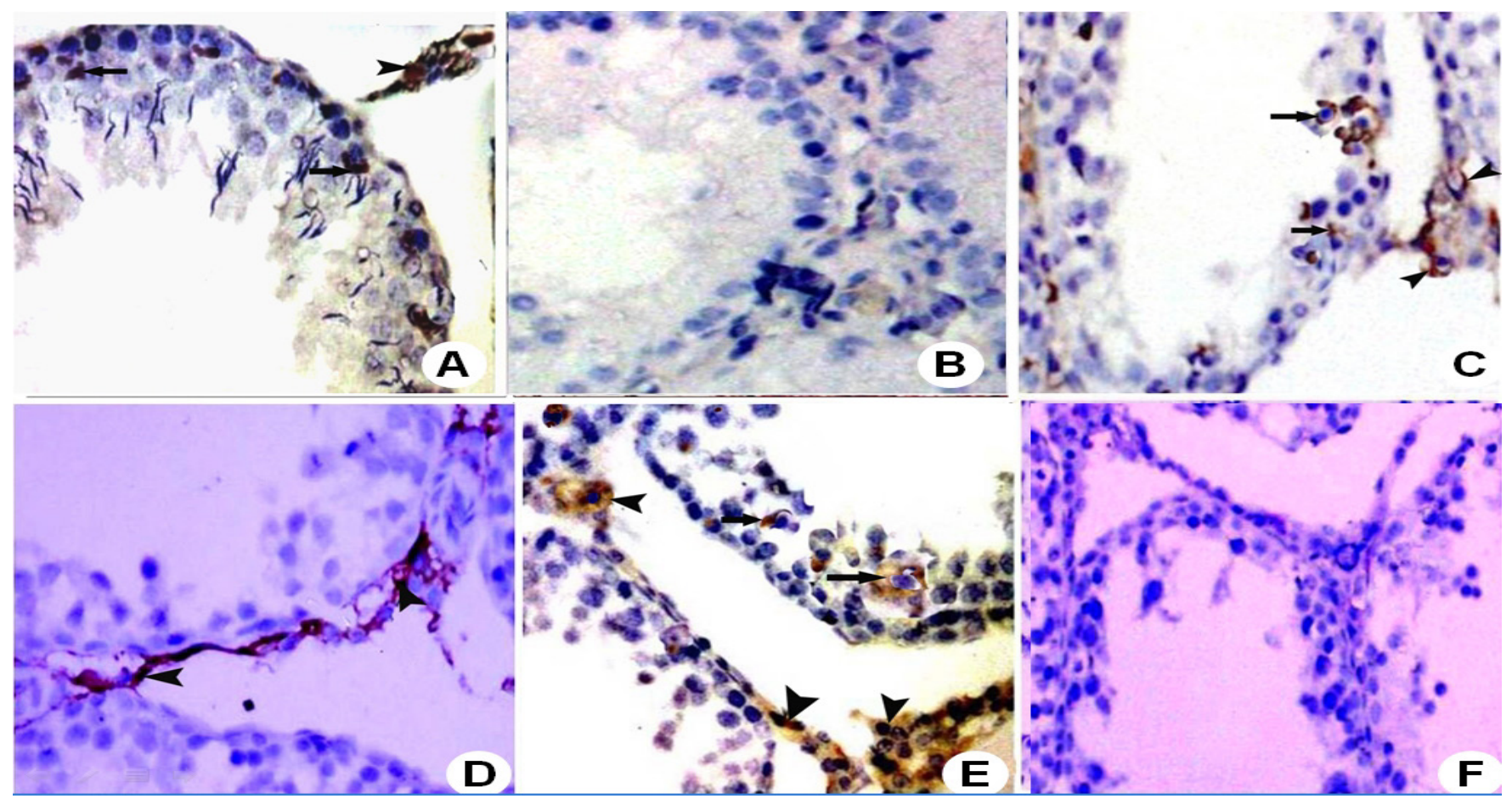

Fig. 4 : (A) showing $+\mathrm{ve} \mathrm{BCl}_{2}$ immunoreaction in the cytoplasm of the spermatogonia (black arrows) and in the cytoplasm of Leydig cells (arrowheads) (group $\mathrm{A}, \mathrm{BCl} 2 \mathrm{X} 1000$ ). (B) showing seminiferous tubules with $-\mathrm{ve}^{\mathrm{BCl}} \mathrm{C}_{2}$ immunoreaction in the cytoplasm of spermatogenic epithelium and interstitial cells (subgroup $\mathrm{B} 1, \mathrm{BCL}_{2} \mathrm{X}$ 1000). (C) showing seminiferous tubuleswith + ve immunoreactions in the cytoplasm of their spermatogenic cells (black arrows) and in the interstitial cells of Leydig (arrowheads) ( subgroup B2, $\mathrm{BCL}_{2} \mathrm{x} 1000$ ). (D) showing negative immunoreaction in the cytoplasm of the spermatogenic cells. There is still positive peritubular immunoreaction (arrowheads) (subgroup B3, $\mathrm{BCL}_{2} \mathrm{X} 1000$ ). (E) showing seminiferous tubuleswith +ve immunoreaction in the spermatogenic cells (black arrows) and in Leydig cell cytoplasm (arrowheads)(subgroup $\mathrm{B} 4, \mathrm{BCl}_{2} \mathrm{x} 1000$ ).(F) showing -ve $\mathrm{BCl}_{2}$ immunoreaction in the spermatogenic cells and Leydig cells (subgroup B5, BCL, X 1000).
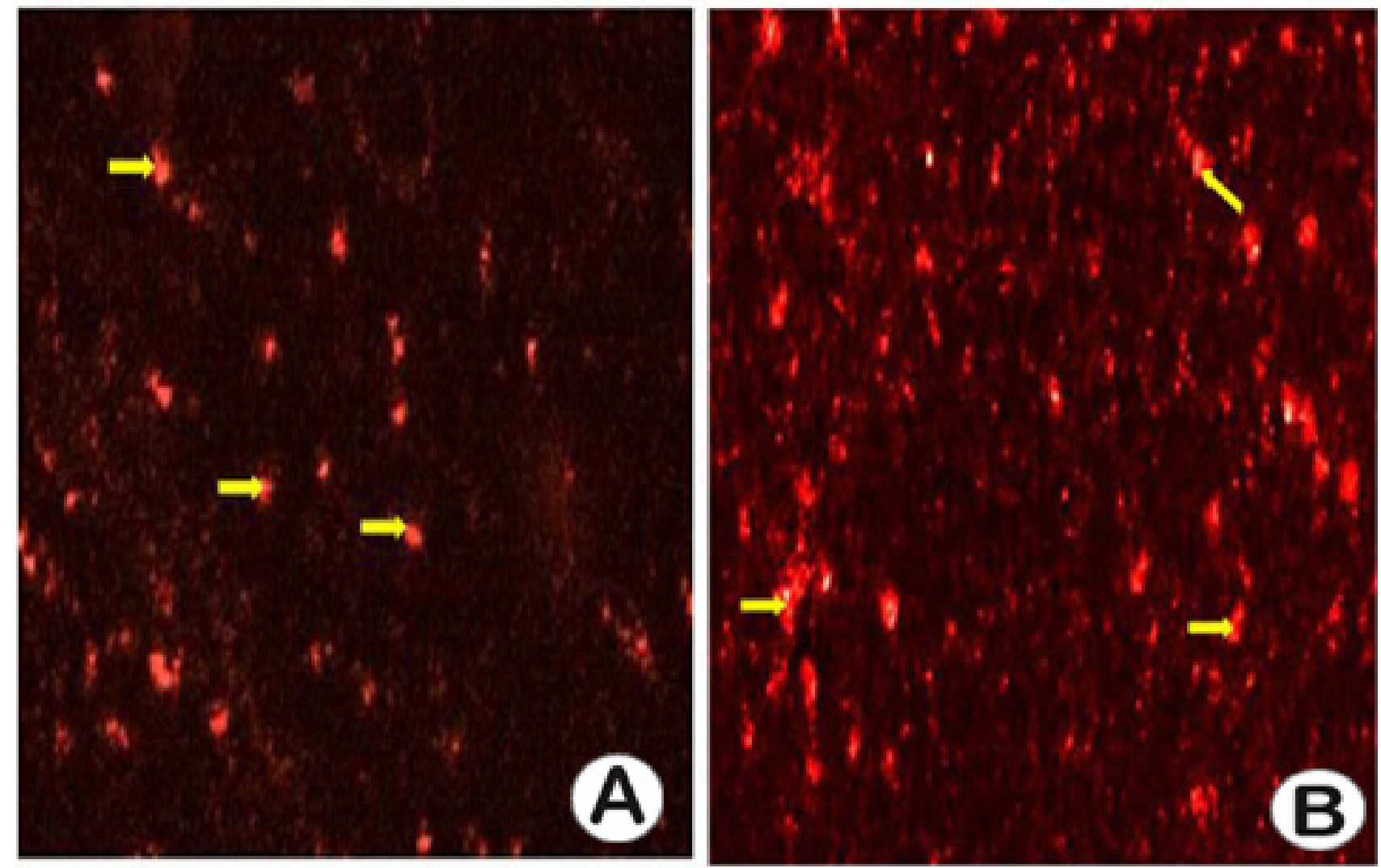

Fig. 5: (A) showing homing of transplanted MSCs (yellow arrows) in testicular tissue (subgroup B2, PKH26x200). (B) showinghoming of transplanted MSCs (yellow arrows) in testicular tissue(subgroup B4 PKH26x200). 

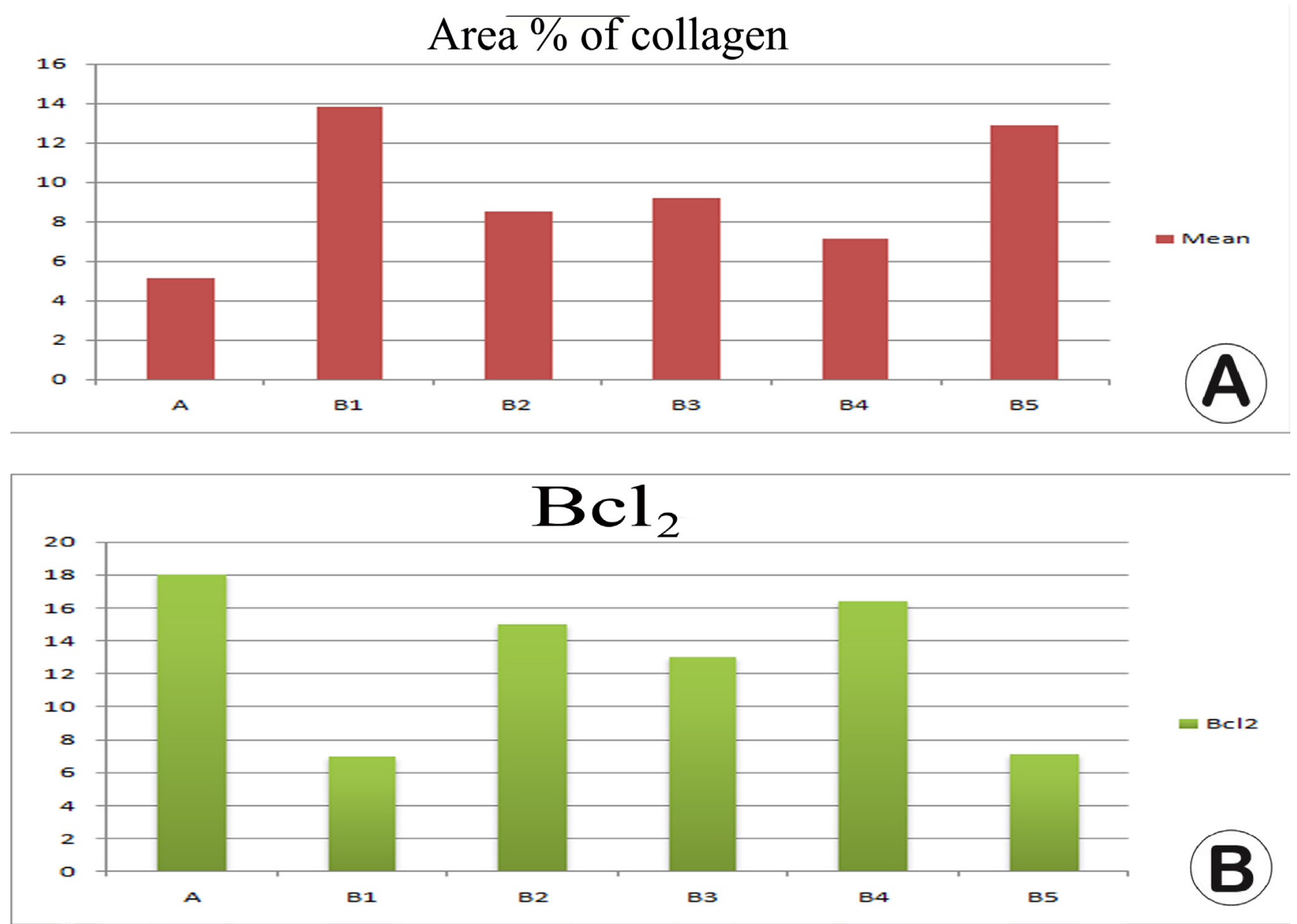

Fig. 6: (A) histogram showing mean area \% of collagen fibers content in the control group and experimental subgroups. (B) histogram showing mean area \% of $\mathrm{BCl}_{2}$ immunoreactivity in the control group and experimental subgroups.

Table 1: Mean area $\%$ of collagen fibers content \pm standard deviation in all groups

\begin{tabular}{lcccccc}
\hline Group & A & B1 & B2 & B3 & B4 \\
\hline Mean area $\% \pm$ SD & $5.12 \pm 0.42$ & $13.8 \pm 1.616$ & $8.51 \pm 0.735$ & $11.19 \pm 0.779$ & $7.13 \pm 0.535$ & $12.9 \pm 1.726$ \\
$P$-value & & $<.001$ & $>.001$ & $<.001$ & $>.001$ & $<.001$ \\
\hline
\end{tabular}

Table 2: Mean area $\%$ of Bcl2 distribution \pm standard deviation in all groups

\begin{tabular}{|c|c|c|c|c|c|c|}
\hline Group & A & B1 & B2 & B3 & B4 & B5 \\
\hline Mean area $\% \pm$ SD & $18.278 \pm 0.52$ & $6.983 \pm 1.726$ & $15.906 \pm 0.779$ & $14.293 \pm 0.735$ & $16.278 \pm 0.81$ & $7.133 \pm 1.726$ \\
\hline P-value & & $<.001$ & $>.001$ & $<.001$ & $>.001$ & $<.001$ \\
\hline
\end{tabular}

\section{DISCUSSION}

The application of $\mathrm{CP}$ as anticancer and immunosuppressive agent is commonly accompanied by reproductive toxicity ${ }^{[22]}$. Human studies showed $\mathrm{CP}$ chemotherapy resulted in prolonged male gonadal injury, diminished testosterone synthesis and depletion of spermatogonia leading to infertility ${ }^{[23]}$. Testicular dysfunction is the most common side effect of $\mathrm{CP}$ chemotherapy among broadly used cytotoxic drugs for the treatment of various cancers ${ }^{[24]}$.
In the present study, HandE stained testicular sections of subgroups B1 (model subgroup) and B5 (recovery subgroup) showed irregular and distorted seminiferous tubules with marked degeneration of the spermatogenic epithelium and congested blood vessels. There were negative immunereactivity in the cytoplasm of spermatogenic, Sertoli or Leydig cells with $\mathrm{BCl}_{2}$ stain. This result correlated with the massive fibrosis detected with Masson's trichrome stain.

Testicular toxicity caused by $\mathrm{CP}$ is due to disturbance of balance between reduction-oxidation reactions in 
tissues resulting in oxidative stress. $\mathrm{CP}$ metabolically activates mixed oxidase system of the hepatic microsomal cytochrome $\mathrm{P} 450$, and this is rated the main mechanism of both the therapeutic and the toxic effects ${ }^{[25] .}$

CP utilization by cells produces the two active metabolites; phosphoramide mustard and acrolein ${ }^{[26]}$. Other documents stated that antineoplastic effects of CP are imported by its phosphoramide mustard metabolite; while the acrolein induces the toxic side effects e.g. cell apoptosis, oncosis, and necrosis. That is in role explains the -ve immunereactivity in the cytoplasm of spermatogenic, Sertoli and Leydig cells with $\mathrm{BCl}_{2}$ stain ${ }^{[27]}$.

In subgroup B2 (stem cells subgroup): HandE stained sections showed preserved arrangement of the seminiferous tubules with minimal vacuolations.Some spermatozoa appeared in the cavity of the tubules. The interstitial tissue contained normally arranged Leydig cells thus revealed remarkable improvement of seminiferous tubulesas compared to subgroup B1. There were some immunereactivity in the cytoplasm of spermatogenic, Sertoli and Leydig cells with BCl2 stain. This result correlated with the diminished fibrosis detected with Masson's trichrome stain.

MSCs have the ability to proliferate, regenerate, transform into differentiated cells, home into the damaged site and finally differentiate into cells specific to the tissue. The differentiation capabilities of MSCs and their relative ease of expansion in culture clearly make MSCs potentially ideal candidates for tissue repair therapy ${ }^{[12]}$. MSCs are able to restore spermatogenesis via differentiation into germ cells then gave rise to sperm-like cells, leading to recovery of fertility in the testicular injury rat model ${ }^{[28]}$.

The antioxidative system is significantly restored by MSCs by increasing the activities of Superoxide dismutase (SOD), Catalase (CAT) and Glutathion peroxidase (GPx) levels in testes tissue. Moreover, MSCs scavenge free radicals from testicular tissues thus protecting against induced oxidative damage. They specifically respond to oxidative stress by regulation of tissue homeostasis and regeneration of organs after oxidative injury ${ }^{[29]}$.

Furthermore, it is reported that MSCs share in restoration of of spermatogenesis in through differentiation into sperm or maintenance of the spermatogonial stem cells. So, MSCs could be a rich and functional line for infertility treatment ${ }^{[30]}$.

In subgroup B3 (LA subgroup): HandE stained sections showed that the spermatogenic epithelium was improved as compared to CP-treated group however, this improvement was less than that in subgroup B2 (stem cells subgroup) and subgroup B4 (stem cells plus LA subgroup). There were -ve immunoreaction in the cytoplasm of the spermatogenic cells, but there is still positive immunoreaction in the cytoplasm of interstitial cells with $\mathrm{BCl}_{2}$ stain. This result correlated with dense fibrosis detected with Masson's trichrome stain.
LA is an effective antioxidant ${ }^{[31]}$. It is able to scavenge ROS in vitro and in vivo. It works both inside the cell and at the membrane level, thereby giving dual protection ${ }^{[32]}$. It creates a strong shield on plasmalemma of the sperm, along with the liquid that surrounds the spermatogenic cells indirectly promote their ability to resist higher volumes of free radicals. It has also been reported to relief the mitochondria's Krebs cycle; this in turn will raise the level of reduced glutathione, ATP, Tricarboxylic acid cycle enzymes and electron transport chain complex activities ${ }^{[33]}$.

Other LA antioxidant effects include its ability to regulate cellular metabolism and increase the level mitochondrial co-enzymes and protect the cells against free radicals leading to reduction of mitochondrial dysfunction and preservation of spermatogenic cells against $\mathrm{ROS}^{[34]}$ Additionally, it regenerates the Glutathione (GSH) pool by reduction of oxidized GSH. Treatment with LA helps to vanquish the oxidative stress by increasing the GSH level, which in turn increases free radical scavenging ability ${ }^{[31]}$.

In subgroup B4 (stem cells plus LA subgroup), sections showed restoration of seminiferous tubules with intact basement membrane. The seminiferous tubules were lined by nearly normal spermatogenic cells with clear primary spermatocytes and spermatids within their centers. There was moderate immunoreactivity in the cytoplasm of spermatogenic and Leydig cells with $\mathrm{BCl}_{2}$ stain. This result correlated with the little fibrosis detected with Masson's trichrome stain.

It is worth notice that, the results of the present study showed that combined LA and MSCs treatment yielded better improvement of $\mathrm{CP}$-induced testicular injury as compared to either LA or MSCs alone.

LA protects testes against GSH depletion ${ }^{[35]}$ and it increases the total GSH content of the seminiferous tubules $^{[36]}$. On the other hand, GSH plays a paramount role in MSCs proliferation and differentiation ${ }^{[37]}$. Testicular differentiation of MSCs is carried out in presence of $\mathrm{N}$-acetylcysteine (the precursor of GSH biosynthesis) ${ }^{[38]}$.

Diminished GSH and Thiobarbituric acid reactive substances (TBARS) are signs of antioxidant condition in biological systems. GSH, an installment of non-enzymatic antioxidant status, helps to effectively strips $\mathrm{H}_{2} \mathrm{O}_{2}$ and serves as a cofactor for GSH transferase, which helps to tear out certain chemicals, drugs and other reactive molecules from tissues ${ }^{[39]}$.

The degenerative changes in seminiferous tubules and their morphology in model and recovery subgroups are due to apoptotic effect on spermatogenic epithelium which was illustrated by histological examination and $\mathrm{BCl}_{2}$ analysis. In this study, subgroups B1 and B5 showed -ve immunoreactivity to $\mathrm{BCl}_{2}$ whenever subgroups $\mathrm{B} 2, \mathrm{~B} 3$ and $\mathrm{B} 4$ showed +ve immunoreactivity. This is assured by morphometric studies that detected significant increase the immunoreactivity of subgroups B2, B3 and B4 more than in subgroups B1 and B5. 


\section{CONCLUSION}

Administration of $\mathrm{CP}$ to rats induced testicular lesions. Withdrawal of the drug did not ameliorate this effect. The concomitant administration of MSCs and LA with CP led to an improvement in testicular lesions induced by CP. Meanwhile, combined treatment with MSCs plus LA resulted in better improvement more than using each one of them singly.

\section{CONFLICTS OF INTEREST}

There are no conflicts of interest.

\section{REFERENCES}

1. Elaine Perobelli, J.: Effects of anticancer drugs in reproductive parameters of juvenile male animals and role of protective agents. Anti-Cancer Agents in Medicinal Chemistry (Formerly Current Medicinal Chemistry-Anti-Cancer Agents), 2017; 17(9), 1199-1210

2. Hasegawa, N., Abei, M., Yokoyama, K. K., Fukuda, K., Seo, E., Kawashima, R., and Obata, Y. : Cyclophosphamide enhances antitumor efficacy of oncolytic adenovirus expressing uracil phosphoribosyltransferase (UPRT) in immunocompetent Syrian hamsters. International Journal of Cancer 2013; 133(6), 1479-1488

3. Mehrabani, D., Hassanshahi, M. A., Tamadon, A., Zare, S., Keshavarz, S., Rahmanifar, F., and Ramzi, M.: Adipose tissue-derived mesenchymal stem cells repair germinal cells of seminiferous tubules of busulfan-induced azoospermic rats. Journal of human reproductive sciences, 2015; 8(2), 103.

4. Ghasemzadeh-Hasankolaei, M., Eslaminejad, M. B., andSedighi-Gilani, M. : Derivation of male germ cells from ram bone marrow mesenchymal stem cells by three different methods and evaluation of their fate after transplantation into the testis. In Vitro Cellular and Developmental Biology-Animal, 2016; 52(1), 49-61.

5. Spees, J. L., Lee, R. H., and Gregory, C. A.: Mechanisms of mesenchymal stem/stromal cell function. Stem Cell Research and Therapy, 2016; $7(1), 125$.

6. Ullah, I., Subbarao, R. B., and Rho, G. J.: Human mesenchymal stem cells - current trends and future prospective. Bioscience Reports, 2015; 35(2), e00191.

7. Zhang, Z. Y., Xing, X. Y., Ju, G. Q., Zhong, L., et al. :Mesenchymal stem cells from human umbilical cord ameliorate testicular dysfunction in a male rat hypogonadism model. Asian journal of andrology,2017; 19(5), 543.

8. Ozbal, S., Ergur, B. U., Erbil, G., Tekmen, I., Bagriyanık, A., andCavdar, Z. : The effects of $\alpha$-lipoic acid against testicular ischemiareperfusion injury in rats. The Scientific World Journal, 2012; Volume 2012, Article ID 489248 , 8 pages

9. Prathima, P., Venkaiah, K., Pavani, R., Daveedu, T., Munikumar, M., Gobinath, M., and Sainath, S B. : $\alpha$-lipoic acid inhibits oxidative stress in testis and attenuates testicular toxicity in rats exposed to carbimazole during embryonic period. Toxicology Reports, 2017; 4, 373-381.

10. Oyenihi, A. B., Ayeleso, A. O., Mukwevho, E., andMasola, B.: Antioxidant Strategies in the Management of Diabetic Neuropathy. BioMed Research International, 2015; 515042

11. Abarikwu, S. O., Otuechere, C. A., Ekor, M., Monwuba, K., andOsobu, D.:Rutin ameliorates cyclophosphamide-induced reproductive toxicity in male rats. Toxicology international, 2012; 19(2), 207.

12. Zhang, D., Liu, X., Peng, J., He, D., et al.: Potential spermatogenesis recovery with bone marrow mesenchymal stem cells in an azoospermic rat model. International journal of molecular sciences, 2014; 15(8), 13151-13165.

13. Yeni, D., Fidan, A. F., Ciğerci, I. H., Konuk, M. et al.: Effect of $\alpha$-lipoic acid on sperm quality, reproductive tract measures in thinner exposed rats. Andrologia, 2012; 44(s1), 74-80.

14. Shaw, O. M., and Harper, J. L. : An efficient single prime protocol for the induction of antigen-induced airways inflammation. Journal of immunological methods, 2013; 395(1), 79-82.

15. Edalatmanesh MA, Matin MM, Neshati Z, Bahrami AR, Kheirabadi M. : Systemic transplantation of mesenchymal stem cells can reduce cognitive and motor deficits in rats with unilateral lesions of the neostriatum. Neurol Res.2010; 32(2):166-172.

16. Rochefort,GY.,Vaudin, P. and Bonnet, N. : Influence of hypoxia on the domiciliation of mesenchymal stem cells after infusion into rats: possibilities of targeting pulmonary artery remodeling via cells therapies. Respir Res., 2005; 16(10): 775-783.

17. Alhadlaq, A. and Mao, JJ. : Mesenchymal stem cells; Isolation and therapeutics. Stem Cells Dev, 2004; 13:436-48.

18. Kiernan JA: Histological and histochemical methods: Theory and Practice. $3^{\text {rd }}$ ed., Arnold publisher, London, New York and New Delhi, 2001; 111-162.

19. Bancroft J.D. and Gamble M.: The Hematoxylins and eosin. In: Theory and practice of histological techniques, $6^{\text {th }}$ ed., Bancroft J.D. and Gamble M. (eds.), Elsevier Health Sciences, 2008; Churchill 
Livingstone, Edinburgh, London, Oxford, New York, Philadelphia, St Louis, Sydney and Toronto, p. 130.

20. Kukner, A., Oner, J., Oner, H., and Ozan, E.: Effect of the vitamin E on expression of apoptosisrelated proteins in immobilized rat testes. Journal of Animal and Veterinary Advances, 2008; 9(1), 180-185.

21. Emsley, R., Dunn, G., and White, IR. : Mediation and moderation of treatment effects in randomized controlled trials of complex interventions.Stat Meth Med Res, 2010; 19(3):237-270.

22. Chul Lee Sung-Hwan Kim, Hyung-SeonBaek, Changjong Moon, Sung-Ho Kim et al.,: Protective effect of diallyl disulfide on cyclophosphamideinduced testicular toxicity in rats,Lab Anim Res. 2013; 29(4): 204-211.

23. De Paula Ramos, S., Goessler, K. F., Ruiz, R. J., Ferrari, O., DoederleinPolito, M., andSparça Salles, M. J. : Exercise protects rat testis from cyclophosphamide-induced damage. Acta Scientiarum Biological Sciences, 2013; 35(1):105-113.

24. Oprea, A. D., Russell, R. R., Russell, K. S., and Abu-Khalaf, M.: Chemotherapy agents with known cardiovascular side effects and their anesthetic implications. Journal of cardiothoracic and vascular anesthesia, 2017; 31(6), 2206-2226.

25. Liu, F., Li, X. L., Lin, T., He, D. W., Wei, G. H., Liu, J. H., and Li, L. S.: The cyclophosphamide metabolite, acrolein, induces cytoskeletal changes and oxidative stress in Sertoli cells. Molecular biology reports, 2012; 39(1), 493-500.

26. Chabra, A., Shokrzadeh, M., Naghshvar, F., Salehi, F., and Ahmadi, A.: Melatonin ameliorates oxidative stress and reproductive toxicity induced by cyclophosphamide in male mice. Human and experimental toxicology, 2012; 33(2), 185-195.

27. Habibi, E., Shokrzadeh, M., Ahmadi, A., Chabra, A., Naghshvar, F., and Keshavarz-Maleki, R.:Genoprotective effects of Origanum vulgare ethanolic extract against cyclophosphamideinduced genotoxicity in mouse bone marrow cells. Pharmaceutical biology, 2015; 53(1), 92-97.

28. Cakici, C.; Buyrukcu, B.; Duruksu, G.; Haliloglu, et al. : Recovery of fertility in azoospermia rats after injection of adipose-tissue-derived mesenchymal stem cells: The sperm generation. BioMed Res. Int., 2013; 529-589.

29. Yang, W., Yang, Y., Yang, J. Y., Liang, M., et al. : Treatment with bone marrow mesenchymal stem cells combined with plumbagin alleviates spinal cord injury by affecting oxidative stress, inflammation, apoptotis and the activation of the Nrf2 pathway. International journal of molecular medicine, 2016; 37(4), 1075-1082.

30. Mello, M. S. C., Delgado, I. F., Favareto, A. P. A., Lopes, C. M., Batista, M. M., Kempinas, W. D. G., andPaumgartten, F. J.: Sexual maturation and fertility of mice exposed to triphenyltin during prepubertal and pubertal periods. Toxicology Reports, 2015; 2, 405-414.

31. Rochette, L., Ghibu, S., Richard, C., Zeller, M., Cottin, Y., andVergely, C.: Direct and indirect antioxidant properties of $\alpha$-lipoic acid and therapeutic potential. Molecular nutrition and food research, 2013; 57(1), 114-125.

32. Roberts, J. L., and Moreau, R.: Emerging role of alpha-lipoic acid in the prevention and treatment of bone loss. Nutrition reviews, 2015; 73(2), 116-125.

33. Rochette, L., Ghibu, S., Muresan, A., andVergely, C.: Alpha-lipoic acid: molecular mechanisms and therapeutic potential in diabetes 1. Canadian Journal of Physiology and Pharmacology, 2015; 93(12), 1021-1027.

34. Bakhtiary, Z., Shahrooz, R., Ahmadi, A., andSoltanalinejad, F.: Ethyl pyruvate ameliorates the damage induced by cyclophosphamide on adult mice testes. International journal of fertility and sterility, 2016; 10(1), 79 .

35. Jana, K., Dutta, A., Chakraborty, P., Manna, I., Firdaus, S. B., Bandyopadhyay, D., and Chakravarty, B.: Alpha-lipoic acid and $\mathrm{N}$-acetylcysteine protects intensive swimming exercise-mediated germ-cell depletion, pro-oxidant generation, and alteration of steroidogenesis in rat testis. Molecular reproduction and development, 2014; 81(9), 833-850.

36. Shi, C., Zhou, X., Zhang, J., Wang, J., Xie, H., and $\mathrm{Wu}, \mathrm{Z} .: \alpha$-Lipoic acid protects against the cytotoxicity and oxidative stress induced by cadmium in HepG2 cells through regeneration of glutathione by glutathione reductase via Nrf2/ARE signaling pathway. Environmental toxicology and pharmacology, 2016; 45, 274-281.

37. Chaudhari, P., Ye, Z., and Jang, Y. Y.: Roles of reactive oxygen species in the fate of stem cells. Antioxidants and redox signaling, 2014; 20 (12), 1881-1890.

38. Li, Y., Yan, M., Yang, J., Raman, I., Du, Y., Min, S., and Li, Q. Z. : Glutathione S-transferase $\mathrm{Mu}$ 2-transduced mesenchymal stem cells ameliorated anti-glomerular basement membrane antibodyinduced glomerulonephritis by inhibiting oxidation and inflammation. Stem cell research and therapy, 2014; 5(1), 1 . 
39. Sumathi, T., Shobana, C., Mahalakshmi, V., Surekha, R., Subathra, M., Vishali, A., and Rekha, K.: Oxidative stress in brains of male rats intoxicated with aluminium and neuromodulating effect of Celastrus paniculatus alcoholic seed extract. Asian J Pharm Clin Res, 2013; 6(3), 80-90. 


\section{الملخص العربى}

\section{دراسة نسيجيه مقارنة بين التأثير المحتمل للخلايا الجذعية و الفاـ حمض اللابيويك على خصي الجرذان المعالجه بالسيكلوفوسفاميد}

\section{ايمان مصطقى صادق'، داليا حسين عبد العزيز`، عزة صالح امبابي'، وجابر فكري جنيدي' قسم علم الأنسجة، كلية الطب، جامعة القاهرة' وجامعة بني سويفن}

إن الخلل الوظيفى للخصية هو اشهر الاعر اض الجانبية للسيكلوفوسفاميد والذى يستخدم على نطاق واسع كمضاد للاور ام ومثبط للمناعه فى زرع الاعضاء. وقد تم الكثف عن الخلايا الجذعية الميزنشيمية وحمض الليبويك للجهاز التناسلي للانسان و الحيو ان و عليه يمكن ان يكون لهما وظيفه هامه لخلايا الجهاز التناسلي. ويهدف هذا العمل الى معرفة مدى تأثير الخلايا الجذعية الميزنشيمية وحمض الليبويك على التغيرات النسيجية و المناعية التى قد تظهر فى خلايا الخصية فى الجرذان التى سبق علاجها بالسيكلوفوسفاميد. وقد شملت هذه الدر اسه إستخدام سبعة وثلاثين من ذكور الجرذان البالغه التى ثر اوح وزنهم ما بين مائة و خمسين الى مائتين جر ام و تم تقسيمهم الى مجمو عتين : المجموعة أ ( المجموعة الضابطة ): عشرة جرذان تم حقنهم فى التجويف البريتونى بمحلول الملح. المجموعة ب (المجموعة التجريبية): سبعة وعشرون جرذا تم حقنه فى البريتون بالاندوكسان مرة كل يومين اسبو عيا لمدة 7 اسابيع ,ثم قسمت الجرذان الى خمس مجمو عات فر عية (خمسة جرذان لكل منها): • مجموعة فرعية ب ا(المجموعة النموذج): تم حقن الجرذان بالسيكلوفوسفاميد المذاب فى محلول الملح فى الغشاء البريتونى كل يومين لمدة الم اسبو عا. • مجمو عة فر عية ب ب (مجمو عة الخلايا الجذعية): تم حقن الجرذان بالسيكلوفوسفاميد كما فى المجمو عة الفرعية ب ا وتم حقنها بجر عة و احدة من الخلايا الجذعية الميزنشيمية (x106 لكل جرذ)فى وريد الذيل بعد ستة اسابيع من بداية التجربة. • مجمو عة فر عية ب ץ (مجمو عة حمض الليبو يك): تم حقن الجرذان بالسيكلوفو سفاميد كما فى المجمو عة الفر عية ب ا وتم حقنها بحمض الليبويك فى الغشاء البريتونى بجر عة • ا مل لكل كجم كل يو مين لمدة ال اسبو عا. • مجموعة فرعية ب ؟ (مجمو عة الخلايا الجذعية مع حمض الليبويك): تم حقن الجرذان بالسيكلوفوسفاميد كما فى المجمو عة الفر عية ب ا علاوة على جر عة و احد من الخلايا الجذعية الميزنشيمية كما فى المجمو عة الفرعية

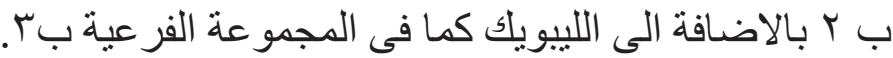
• مجموعة فرعية ب ه (مجمو عة التعافى): تركت بدون اى علاج لمدة ال اسبوعا. 
وفى نهاية التجربة تم التضحيه بالجرذان ثم استنصسال الخصي منها حيث عولجت لإعداد قطاعات شمعية وتجهيز هاوتم صبغها بالهيماتوكسيلين و الايوسين وصبغة الماسون ثلاثى الالوان و الصبغه الهستوكيميائية المناعيه للبروتين المضاد للموت المبرمج ثم تم عمل در اسة كمية قياسية. وقد اظهرت النتائج للمجمو عنين الفرعيتين ب ا وب ه ان هناك تحريفا فى بعض القنوات المنويه وضمور فى الخلايا المولده للنطاف وكذلك التليف حول الاوعيه والقنوات المنويه و النتائج السلبيه للصبغه المناعيه. إلا إنه عند استخدام الخلايا الجذعية الميزنشيمية وحمض الليبويك فى المجموعات الفرعيه ب بو ساوك ظهر تحسن ملحوظ فى كافة التغير ات المذكوره اعلاه,ولكن ذلك التحسن الذى ظهر فى مجمو عة ب ب المعالجة بالخلايا الجذعية كان افضل منه فى مجمو عة ب بالمعالجة بحمض الليبويك,فى حين ان ادماج العلاج بكلا من الخلايا الجذعية الميزنشيمية وحمض الليبويك فى المجموعة ب؛ اظهر تحسنا فى القنوات المنويه و الخلايا المولده للنطاف افضل بكثير عنه من استخدام كل منهما على حدة.

الاستنتاج: اثتتت الدر اسه التأثير المدمر لعقار السيكلوفوسفاميد على نسيج الخصيه فى الجرذان كما ان انسحاب العقار لم يحسن من هذه التغير ات و لكن اعطاء الخلايا الجذعية الميزنشيمية أوحمض الليبويك مع السيكلوفوسفاميد اظهر تحسنا جزئيا في حماية انسجة الخصيه من التأثير الضار لعقار السيكلوفوسفاميد وان ادماج العلاج بكلا من الخلايا الجذعية الميزنشيمية وحمض الليبويك اظهر تحسنا افضل بكثير منه عند استخدام كل منهما على حدة. 